\title{
Influence of the Annealing Temperature on the Structure and Properties of Bismuth Ferrites
}

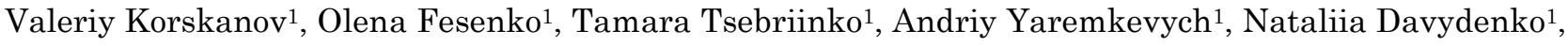 \\ Volodymyr Dolgoshey2,*, Alina Semchenko ${ }^{3}$, Vitalii Sidsky ${ }^{3}$
1 Transfer Technology Department, Institute of Physics of the NASU, 46, Prospect Nauki, 03039 Kyiv, Ukraine
2 NTUU "KPI named after Igor Sikorsky", 37, Peremohy Ave., 03056 Kyiv, Ukraine \\ ${ }^{3}$ Francisk Skorina Gomel State University, 104, Sovetskaya St., 246019 Gomel, Belarus
}

(Received 16 April 2021; revised manuscript received 20 October 2021; published online 25 October 2021)

\begin{abstract}
This article presents samples of bismuth ferrite developed and synthesized by the authors using the solgel method. SEM images of such samples were obtained. The data from X-ray diffraction analysis and thermodynamic properties of these bismuth ferrites were studied. It was found that samples annealed at different temperatures have a granular microstructure with granule sizes from 20 to $100 \mathrm{~nm}$. On a scale above $200 \mathrm{~nm}$, all samples are morphologically indistinguishable. The X-ray diffraction study discovered the crystallinity of bismuth ferrites at a scale level of less than one nanometer. The sizes of nanocrystallites of bismuth ferrite and overall structural heterogeneity decrease with increasing annealing temperature. The thermodynamic analysis found a significant decrease in heat capacity, enthalpy, entropy and modulus of the Gibbs energy of the samples under study with an increase in the annealing temperature. This indicates an improvement in the structure due to reducing heat loss on structural defects. A direct correlation between the level of X-ray scattering on the studied samples and the thermodynamic properties of bismuth ferrites was established. There is reason to believe that by selecting an appropriate annealing temperature, it is possible to regulate the nanocrystallinity and thus other physical properties of bismuth ferrites.
\end{abstract}

Keywords: Bismuth ferrites, Morphology, X-ray diffraction study, Thermodynamic properties, Nanocrystallinity.

DOI: 10.21272/jnep.13(5).05004

PACS numbers: 61.05.cp, 68.35.Md

\section{INTRODUCTION}

In the past decade, considerable attention has been devoted to the study of bismuth ferrites as the material that is characterized by both magnetic and strong ferroelectric properties at room temperature [1-6].

Various modifications of bismuth ferrite are widely used as the newest progressive innovative materials for anodes in sodium-ion batteries [7], in memory devices [12], for use in supercapacitors, solar cells, etc.

The traditional ceramic method for obtaining ferromagnetic materials today is being actively replaced by chemical methods for the synthesis of such materials. This tendency is associated with the sufficient timeconsuming of the traditional method. In addition, its serious disadvantage is also the irregularity of the shape, size and stoichiometry of materials which may result in nonreproducible ferrite products. Also, chemical synthesis approaches have the advantage over the ceramic method because (i) it requires low temperatures, (ii) makes it possible to obtain small nano-sized particles, (iii) the method is easy and cheap and requires less time, (iv) stoichiometry does not change, (v) and importantly the product is reproducible. Among the available chemical methods, sol-gel synthesis is known as a universal method that allows the synthesis of nanoparticles with chemical composition and crystallography similar to particles obtained by solid-state reactions but with better morphology owing to fine particle size [26].

Sol-gel synthesis is a two-step process $[10,27]$. In the first stage, as a result of the reaction of hydrolysis of a chemical substance, in which metals or metalloids are surrounded by ligands, for example, nitrates of the corresponding metals, a colloidal "sol" is formed. At the second stage, the sol polymerization (condensation) occurs with the formation of a larger metal-containing molecule. When the molecule reaches its macroscopic size, spreading throughout the solution, the resulting substance is called a "gel". The advantage of the sol-gel technology is the homogeneity of the initial mixtures (precursors) and the reduced loss of bismuth due to much lower temperatures.

Numerous studies have shown that the basic properties of bismuth ferrites depend not only on the choice of the most effective method of their synthesis, but also to a greater degree on their physical annealing in the equilibrium melt and subsequent cooling. Since the structure of the final nanocrystalline material depend on crystallization, this structuring method has been successfully used by many researchers for a long time $[11,15,16,22,23]$.

Therefore, this work presents the results of studies of the effect of different annealing temperatures on the structural organization and thermodynamic properties of bismuth ferrite materials.

\section{OBJECTS OF STUDY AND EXPERIMENTAL METHODS}

An effective new method for producing bismuth ferrite samples by using sol-gel synthesis was developed by the authors.

The synthesis of $\mathrm{BiFeO}_{3}$ powders was carried out using separate hydrolysis of each precursor (iron ni-

\footnotetext{
*vdolgoshey@ukr.net
} 
trate nonahydrate $\mathrm{Fe}\left(\mathrm{NO}_{3}\right)_{3} \times 9 \mathrm{H}_{2} \mathrm{O}, 99 \%$ purity, and bismuth nitrate pentahydrate $\mathrm{Bi}\left(\mathrm{NO}_{3}\right)_{3} \times 5 \mathrm{H}_{2} \mathrm{O}, 99 \%$ purity, both from Merck) with their subsequent mixing. It was found that the use of separate hydrolysis improves the ferroelectric properties of the obtained powders. This is due to the fact that at the stage of preparing the sol when using the same solvent, separate hydrolysis occurs completely for each of the metal compounds in comparison with joint hydrolysis, where, due to different reaction rates, some metals are not completely hydrolyzed [10].

In the first step, $\mathrm{Fe}\left(\mathrm{NO}_{3}\right)_{3} \times 9 \mathrm{H}_{2} \mathrm{O}$ was mixed with a solution of dilute citric acid $\left(\mathrm{C}_{6} \mathrm{H}_{8} \mathrm{O}_{7}\right)$ and glycerol $\mathrm{C}_{3} \mathrm{H}_{8} \mathrm{O}_{3}$ (volume ratio 1:4) to form $\mathrm{Fe}$ precursor solution. The solution was continuously stirred for $30 \mathrm{~min}$ at $50{ }^{\circ} \mathrm{C}$ to completely dissolve ferric nitrate. Citric acid and glycol were used as the chelating agents. Bi precursor solution was obtained through a similar process using $\mathrm{Bi}\left(\mathrm{NO}_{3}\right)_{3} \times 5 \mathrm{H}_{2} \mathrm{O}$. In the second step, Fe precursor solution was mixed with $\mathrm{Bi}$ precursor solution maintaining a molar ratio of $\mathrm{Fe}: \mathrm{Bi}$ mixture to $1: 1.05$, followed by continuous ultrasonic stirring for $30 \mathrm{~min}$ at $25{ }^{\circ} \mathrm{C}$. The resultant precursor solution was transparent as well as homogeneous. The as-prepared precursor solution was kept for aging at $25^{\circ} \mathrm{C}$ for $48 \mathrm{~h}$.

After that, the resulting nanopowders were annealed in a muffle furnace at temperatures of 600,650 and $700{ }^{\circ} \mathrm{C}$ for $1 \mathrm{~h}$ and then cooled to room temperature in a muffle furnace after turning off its heating. Here and further the samples are indicated as bismuth ferrite/600, bismuth ferrite/650 and bismuth ferrite/700, respectively. The sample preparation scheme is shown in Fig. 1.

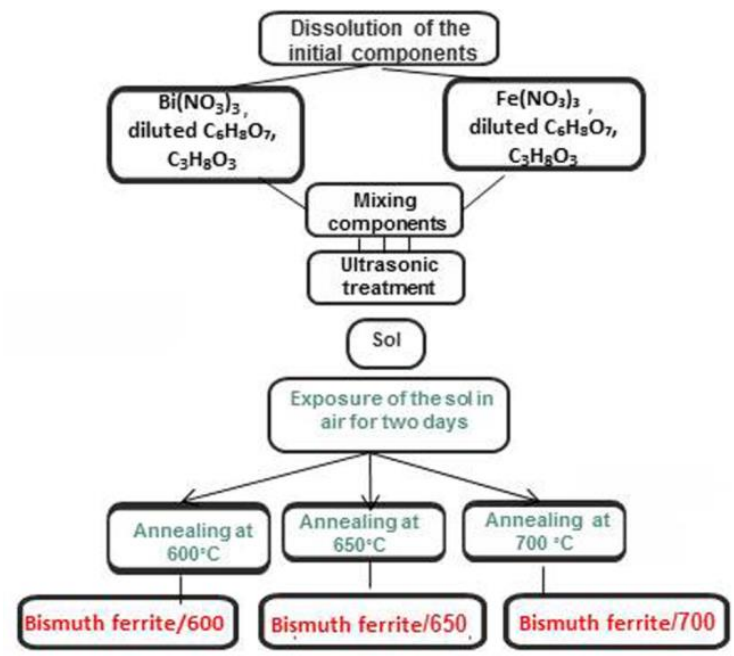

Fig. 1 - The sample preparation scheme

Fig. 1 shows that until the last stage of obtaining bismuth ferrites (annealing at high temperatures), all samples had the same chemical composition. In addition, thermogravimetric analysis showed a relative weight loss before and after the annealing procedure of all materials obtained of less than $1 \%$. Consequently, the final samples of bismuth ferrite differ only in the crystal structure that is formed as a result of nonisothermal crystallization from the previous annealing temperature.
The quality of the samples obtained can be evaluated from SEM images (Fig. 2).

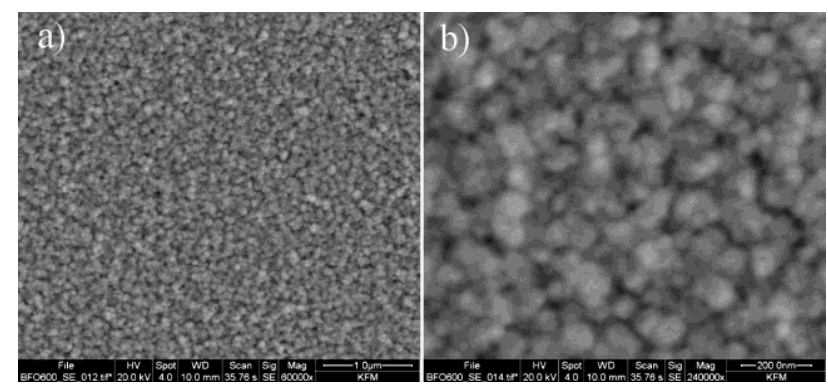

Fig. 2 - SEM images of bismuth ferrite/600

SEM/EDS analysis was carried out in high vacuum using a JEOL JSM 6490LV scanning electron microscope (SEM) coupled with an Oxford INCA energy dispersive spectroscopy (EDS) system, comprising Oxford INCA PentaFET $\times 3 \mathrm{Si}(\mathrm{Li})$ detector and INCA Energy 350 processing software, at $20 \mathrm{kV}$ accelerating voltage, $50 \mathrm{~nm}$ spot size and $10 \mathrm{~mm}$ working distance.

The X-ray diffraction data were obtained in a scattering range $2 \theta$ from 10.04 to 100 degrees with a step of 0.04 degrees by diffractometer Ulnima4 (Ridaku Americas Corporation (USA), $\mathrm{CuK}_{\mathrm{a}}$ radiation, wavelength $\lambda=1.54 \AA$ ). X-ray structural analysis and distribution of components in samples were carried out using internal software and databases of the Ulnima4.

The study of the heat capacity for thermodynamic analysis in the temperature range from 40 to $100{ }^{\circ} \mathrm{C}$ was carried out using a calorimetric module which was described in detail earlier $[8,12]$.

\section{RESULTS AND DISCUSSION}

The SEM images of one sample are shown in Fig. 2 on two scales.

From Fig. 2, it is seen that the morphology of bismuth ferrite/600, bismuth ferrite/650 and bismuth ferrite/700 samples is the same. All samples have a granular microstructure with granule sizes from 20 to $100 \mathrm{~nm}$. This means that on a scale above $200 \mathrm{~nm}$, all samples are morphologically indistinguishable and structural features occur at smaller scale levels. To study a smaller-scale structure, we investigated the nanocrystallinity of the samples by the method of XRD diffraction.

\subsection{X-ray Diffraction Study}

The XRD study was carried out in a scattering range $2 \theta$ from 10.04 to 100 degrees, which corresponds to the scale sizes from 0.88 to $0.001 \mathrm{~nm}$.

In Fig. 3, X-ray scattering curves of bismuth ferrites are shown. One can see that the intensity of X-ray scattering and the quantity of crystalline peaks in the XRD patterns decrease with increasing annealing temperature.

On the X-ray scattering curves of bismuth ferrite/600 33 peaks were found, on the X-ray curves of bismuth ferrite/650 - less than 31 peaks, and on the Xray curves of bismuth ferrite/700 - only 25 peaks. This means that with increasing annealing temperature, the 
heterogeneity of the samples decreases.

Using the software of the Ultima-4 diffractometer, three types of crystallites were found in the samples and the characteristic average parameters of the crystal lattices were detected (Table 1).

Analyzing the results of Table 1, it should be noted that with an increase in the annealing temperature:

- the number of crystallites $\mathrm{Bi}_{2} \mathrm{Fe}_{4} \mathrm{O}_{9}$ and amount of bismuth decreases, while the average amount of $\mathrm{BiFeO}_{3}$ remains constant;

- the characteristic dimensions and volumes of crystallites of bismuth ferrites increase, while for bismuth they remain the same;

- the type of crystallites does not depend on the temperature of pre-annealing.

These results are quite consistent with the theory of non-isothemal crystallization of composite materials, which is based on the mechanism of nucleation for the formation and growth of crystallites [4, 24]. This means that when cooling the equilibrium melt from high temperatures, crystallization begins only after the appearance of density fluctuations in the material, which are nucleation centers to continue their further crystallization [19-21]. According to the theory of non-isothemal crystallization, if the material is cooled from the state of the equilibrium melt at temperatures that significantly exceed the melting point of crystallites, then crystallites with large sizes are formed. If the annealing temperature is slightly higher than the melting point of crystallites, then at the initial stage of the formation of the material a large number of nucleation centers appear. As a result, small crystallites are formed.

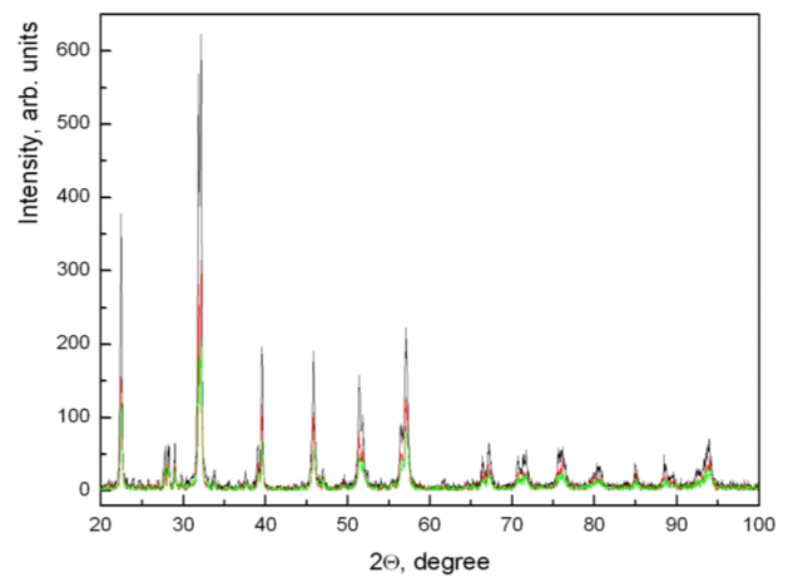

Fig. 3 - The XRD pattern of bismuth ferrite/600 (black line), bismuth ferrite/650 (red line) and bismuth ferrite/700 (green line)

Table 1 - Average parameters of crystal lattices

\begin{tabular}{|c|c|c|c|c|c|c|c|c|c|}
\hline Phase name & $n *$ & $a(\mathrm{~nm})$ & $b(\mathrm{~nm})$ & $c(\mathrm{~nm})$ & $\alpha$ (deg.) & $\beta$ (deg.) & $\gamma$ (deg.) & \begin{tabular}{|c|}
$\begin{array}{c}\text { Volume, } \\
\left(\mathrm{nm}^{3}\right)\end{array}$ \\
\end{tabular} & $\begin{array}{c}\text { Crystal systems } \\
\text { (syngony) }\end{array}$ \\
\hline \multicolumn{10}{|c|}{ Bismuth ferrite/600 } \\
\hline $\mathrm{BiFeO}_{3}$ & 5 & 0.56 & 0.56 & 0.69 & 90.0 & 90.0 & 120.0 & 0.216 & hexagonal \\
\hline $\mathrm{Bi}_{2} \mathrm{Fe}_{4} \mathrm{O}_{9}$ & 14 & 0.79 & 0.84 & 0.60 & 90.0 & 90.0 & 90.0 & 0.398 & rhombohedral \\
\hline Bismuth & 14 & 0.47 & 0.47 & 0.47 & 90.0 & 90.0 & 90.0 & 0.104 & rhombohedral \\
\hline \multicolumn{10}{|c|}{ Bismuth ferrite/650 } \\
\hline $\mathrm{BiFeO}_{3}$ & 5 & 0.57 & 0.57 & 1.38 & 90.0 & 90.0 & 120.0 & 0.448 & hexagonal \\
\hline $\mathrm{Bi}_{2} \mathrm{Fe}_{4} \mathrm{O}_{9}$ & 13 & 0.80 & 0.86 & 0.62 & 90.0 & 90.0 & 90.0 & 0.426 & rhombohedral \\
\hline Bismuth & 13 & 0.47 & 0.47 & 0.47 & 90.0 & 90.0 & 90.0 & 0.104 & rhombohedral \\
\hline \multicolumn{10}{|c|}{ Bismuth ferrite/700 } \\
\hline $\mathrm{BiFeO}_{3}$ & 5 & 0.58 & 0.58 & 1.39 & 90.0 & 90.0 & 90.0 & 0.466 & hexagonal \\
\hline $\mathrm{Bi}_{2} \mathrm{Fe}_{4} \mathrm{O}_{9}$ & 8 & 0.82 & 0.87 & 0.63 & 90.0 & 90.0 & 90.0 & 0.450 & rhombohedral \\
\hline Bismuth & 12 & 0.47 & 0.47 & 0.47 & 90.0 & 90.0 & 90.0 & 0.104 & rhombohedral \\
\hline
\end{tabular}

* number of peaks

According to the fundamental theory of X-ray scattering $[5,14]$, the absolute total intensity of X-ray scattering by the sample is proportional to its heterogeneity and can be calculated as:

$$
I_{\text {total }}=\sum_{2 \theta=10.04}^{100} I(2 \theta),
$$

where $I(2 \theta)$ is the intensity of X-ray scattering at each scattering angle.

Dependence of the total intensity of X-ray scattering on the annealing temperature is shown in Fig. 4.

The software of the Ultima-4 diffractometer makes it possible to construct diagrams of the distribution of components in all samples of bismuth ferrite (Fig. 5).

Fig. 5 shows that an increase in the annealing temperature is accompanied by a decrease in the amount of bismuth ferrite, which is in good agreement with the literature $[15,22,25]$.

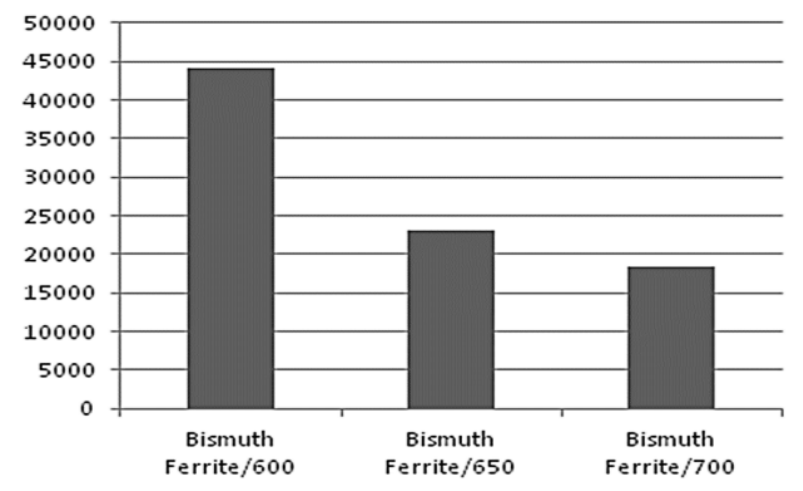

Fig. 4 - Dependence of the total intensity of X-ray scattering $I_{\text {total }}$ on the annealing temperature

According to the literature, the electron density of a chemical element is the result of dividing its molar mass $M$ by the volume $v$ of the atom: 


$$
\rho_{e l}=M / v=M /\left(4 / 3 r^{3}\right),
$$

where $r$ is the radius of the atom.

For bismuth, the molar mass is $209 \mathrm{~g} / \mathrm{mol}$, the radius of the atom is 96 picometers, the volume of the atom $v_{B i}$ is $\approx 1.12 \cdot 10^{-30} \mathrm{~m}^{3}$. Therefore, the theoretical (calculated) electron density $\rho_{B i} \approx 1.87 \cdot 10^{32} \mathrm{~g} /\left(\mathrm{mol} \cdot \mathrm{m}^{3}\right)$. For iron, the molar mass is $56 \mathrm{~g} / \mathrm{mol}$, the radius of the atom is 74 picometers, the volume of the atom $v_{B i}$ is $\approx 5.4 \cdot 10^{-31} \mathrm{~m}^{3}$. Therefore, $\quad \rho_{F e} \approx 1.04 \cdot 10^{32} \mathrm{~g} /\left(\mathrm{mol} \cdot \mathrm{m}^{3}\right)$. And for oxygen, the molar mass is $16 \mathrm{~g} / \mathrm{mol}$, the radius of the atom is 74 picometers, the volume of the atom $v_{B i}$ is $\approx 5.46 \cdot 10^{-33} \mathrm{~m}^{3}$. So, $\rho_{0} \approx 2.93 \cdot 10^{33} \mathrm{~g} /\left(\mathrm{mol} \cdot \mathrm{m}^{3}\right)$.

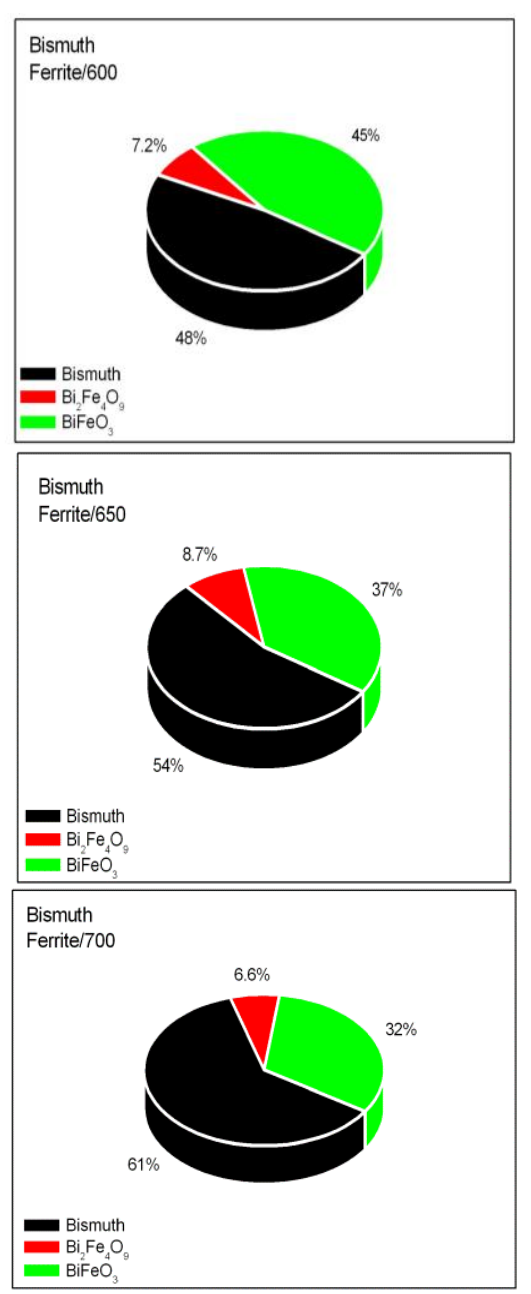

Fig. 5-Diagrams of the distribution of components in the studied samples

Similarly, for bismuth ferrite pbismuth ferrite $\approx$ $\left(1.87 \cdot 10^{32}+1.04 \cdot 10^{32}+3 \cdot 2.93 \cdot 10^{33}\right) \mathrm{g} /\left(\mathrm{mol} \cdot \mathrm{m}^{3}\right)=8.8 \cdot 10^{33}$ $\mathrm{g} /\left(\mathrm{mol} \cdot \mathrm{m}^{3}\right)$ and for dibismuth ferrite $\rho_{\text {dibismuth ferrite } \approx}$ $\left(2 \cdot 1.87 \cdot 10^{32}+4 \cdot 1.04 \cdot 10^{32}+9 \cdot 2.93 \cdot 10^{33}\right) \mathrm{g} /\left(\mathrm{mol} \cdot \mathrm{m}^{3}\right)=$ $2.6 \cdot 10^{34} \mathrm{~g} /\left(\mathrm{mol} \cdot \mathrm{m}^{3}\right)$.

Analyzing the composition of the samples in Fig. 5, you can calculate their average electron density (see Table 2).

According to the generally accepted concepts of Xray scattering by electron density fluctuations [5, 14], these data confirm the earlier conclusion that the heterogeneity of materials decreases with increasing annealing temperature.
Table 2 - Average electron density of different samples

\begin{tabular}{|c|l|}
\hline Sample & \multicolumn{1}{|c|}{$\begin{array}{c}\text { Average electron density of } \\
\text { the samples, } \mathbf{g} /\left(\mathbf{m o l} \cdot \mathbf{m}^{\mathbf{3}} \mathbf{)}\right.\end{array}$} \\
\hline Bismuth ferrite/600 & $\left(0.48 \cdot 1.87 \cdot 10^{32}+0.45 \cdot 8.8 \cdot 10^{33}+\right.$ \\
& $\left.0.072 \cdot 2.6 \cdot 10^{34}\right) / 3 \approx 2.23 \cdot 10^{33}$ \\
\hline Bismuth ferrite/650 & $\left(0.54 \cdot 1.87 \cdot 10^{32}+0.37 \cdot 8.8 \cdot 10^{33}+\right.$ \\
& $\left.0.087 \cdot 2.6 \cdot 10^{34}\right) / 3 \approx 1.90 \cdot 10^{33}$ \\
\hline Bismuth ferrite/700 & $\left(0.61 \cdot 1.87 \cdot 10^{32}+0.32 \cdot 8.8 \cdot 10^{33}+\right.$ \\
& $\left.0.066 \cdot 2.6 \cdot 10^{34}\right) / 3 \approx 1.58 \cdot 10^{33}$ \\
\hline
\end{tabular}

Thus, we discovered the crystallinity of bismuth ferrites at a scale level of less than one nanometer. The bismuth ferrite nanocrystallinity decreases with increasing annealing temperature. Obviously, this heterogeneity at the level of defects will determine most of the physical macroscopic properties of these materials.

\subsection{Thermodynamic Properties}

The study of the effect of the annealing temperature of bismuth ferrite on the thermodynamic properties was carried out using a calorimetric module described in more detail than earlier $[8,12]$.

Experimental measurements of the heat capacity as data for further thermodynamic analysis were used.

By definition, the isobaric heat capacity can be calculated using the following equation:

$$
C_{p}=(d Q / d T) / m=(d Q / d T) / \rho v,
$$

where $d Q / d T$ is the relative heat flow, $m$ is the sample mass, $\rho$ is the sample density, $v$ is the sample volume.

In the case of a stationary heat flow, $d Q / d T=$ const is the same for all measurements.

The total heat loss in the process of heating of the material from temperature $T_{1}$ to temperature $T_{2}$ is:

$$
d Q=d Q_{\text {heating }}+d Q_{\text {loss }},
$$

where $d Q_{\text {heating }}$ is the heat used to heat the sample and $d Q_{\text {loss }}$ is the heat loss due to structure defects. This means that the smaller $d Q_{\text {loss }}$, the lower $C_{p}$.

Thermodynamic potentials can be calculated by processing the experimental results of measuring the specific heat capacity $C_{p}$ (Fig. 6).

The change in the enthalpy of the thermodynamic system $\Delta H$ during heating from temperature $T_{1}$ to temperature $T_{2}$ is calculated according to the following equation $[18,3]$ :

$$
\Delta H\left(T_{1} \rightarrow T_{2}\right)=\int_{T_{1}}^{T_{2}} C_{p}(T) d T .
$$

The change in entropy at each temperature $T_{i}$ $\left(T_{1} \leq T_{i} \leq T_{2}\right)$ is found as [18]:

$$
\Delta S_{T_{i}}=\Delta H_{T_{i}} / T_{i} .
$$

The free energy (or Gibbs energy) $(G)$ is determined as follows [9]:

$$
\Delta G_{T_{i}}=\Delta H_{T_{i}}-T_{i} \cdot \Delta S_{T_{i}}
$$

If the entropy of the thermodynamic system of the same chemical composition decreases in the transition 
from one state to another $(\Delta S<0)$, then the finite system is considered to be more ordered. If it increases $(\Delta S>0)$, then more disordered.

As can be seen from Eq. (5), the change in the free energy $(\Delta G)$ during the transition from one thermodynamic state to another is determined by two components: the change in the enthalpy $\Delta H$ and the change in entropy $\Delta S$. This means, if $\Delta G=\Delta H-T \Delta S>0$, then the process is thermodynamically disadvantageous, i.e., $T \Delta S<\Delta H$ and this leads to a decrease in the free energy (ordering of the thermodynamic system). Conversely, if $\Delta G=\Delta H-T \Delta S>0$, i.e., $T \Delta S>\Delta H$, then the process is thermodynamically advantageous and leads to disorder of the system.

Measurements of the heat capacity of all samples were carried out in the same temperature range for the convenience and correctness of further analysis; comparison and discussion of the results are presented in Fig. 6.

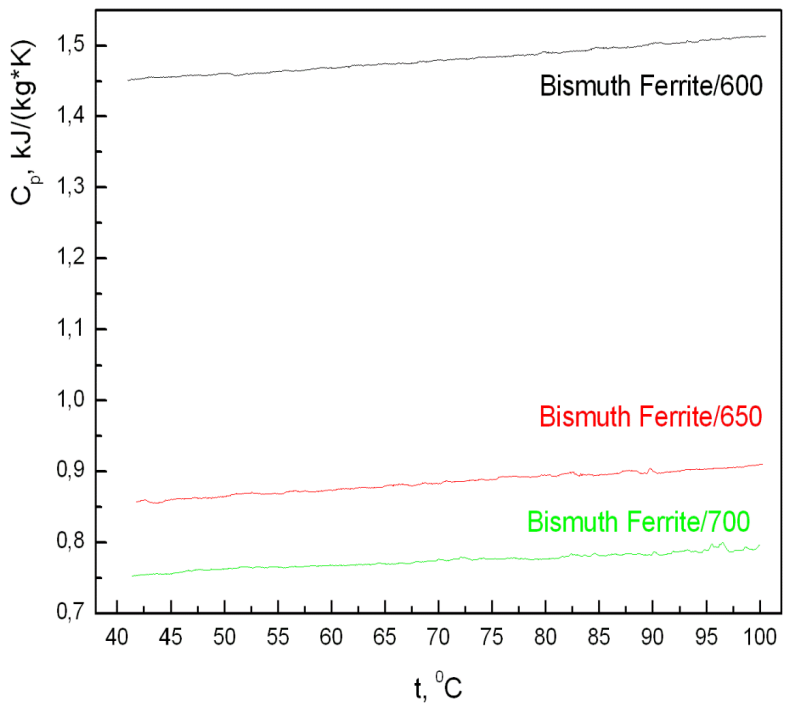

Fig. 6 - Temperature dependences of the heat capacity of bismuth ferrites

A significant decrease in the heat capacity of the samples with an increase in the annealing temperature indicates an increase in the density of crystallite packing, which leads to an increase in the sample density (see an increase in the density in Eq. (1), as well as due to a decrease in heat loss on structural defects (see Eq. (2)).

According to modern ideas, the heat loss is due to scattering of thermal phonons by density fluctuations. In our case, smaller $C_{p}$ for bismuth ferrite/700 sample is fully consistent with the results of XRD studies (see above).

The enthalpy of thermodynamic systems was defined according to Eq. (3) (Fig. 7). A decrease in the enthalpy of bismuth ferrite with an increase in the annealing temperature (Fig. 7) means a decrease in heat loss $d Q_{\text {loss }}$ on structural defects in the sample (the same as for heat capacity).

As you can see from Fig. 8, the change in entropy $S$ of bismuth ferrites of the same chemical composition decreases with an increase in the annealing temperature. This means that the structural ordering of such a thermodynamic system is improved.

A decrease in the absolute value (modulus) of the free energy with an increase in the annealing temperature in Fig. 9 means a decrease in the entropy component $T_{i} \cdot \Delta S_{T_{i}}$ in Eq. (5). This also confirms the increase in thermodynamic ordering with increasing annealing temperature of the samples.

Therefore, all the thermodynamic properties of the samples depend on scattering of thermal phonons by density fluctuations [2 17].

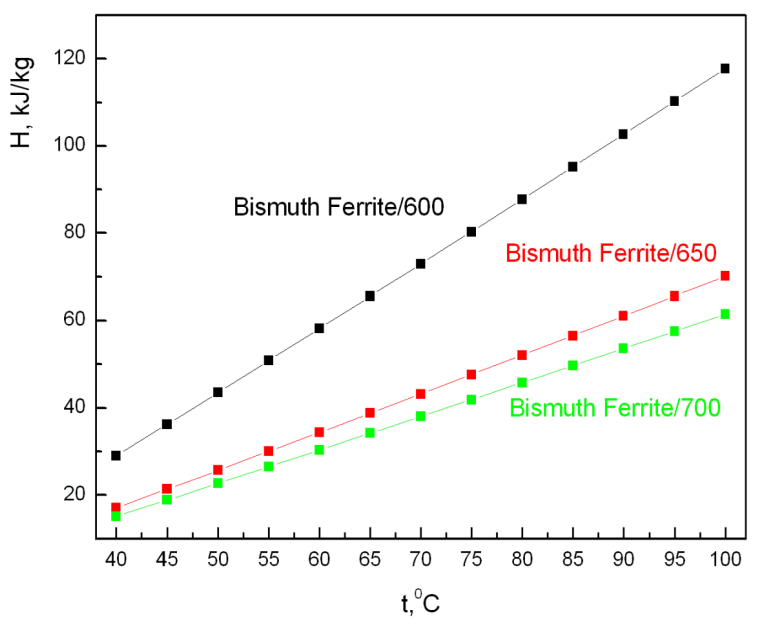

Fig. 7 - Temperature dependences of the enthalpy of bismuth ferrites

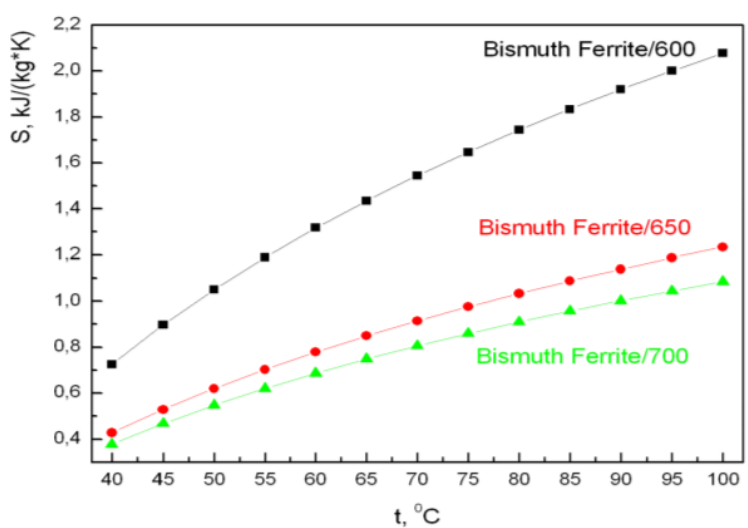

Fig. 8-Temperature dependences of the entropy of bismuth ferrites

Thus, based on thermodynamic analysis of bismuth ferrites, the following preliminary conclusions can be drawn:

i) a significant decrease in heat capacity, enthalpy, entropy and modulus of the Gibbs energy of the samples under study with an increase in the annealing temperature indicates an improvement in the structure due to a decrease in heat loss on structural defects;

ii) the structure of the samples is formed according to the mechanism of joint crystallization of the components during cooling from the annealing temperature to room temperature;

iii) samples obtained after annealing at the maximum temperature are characterized by the least defectiveness. 


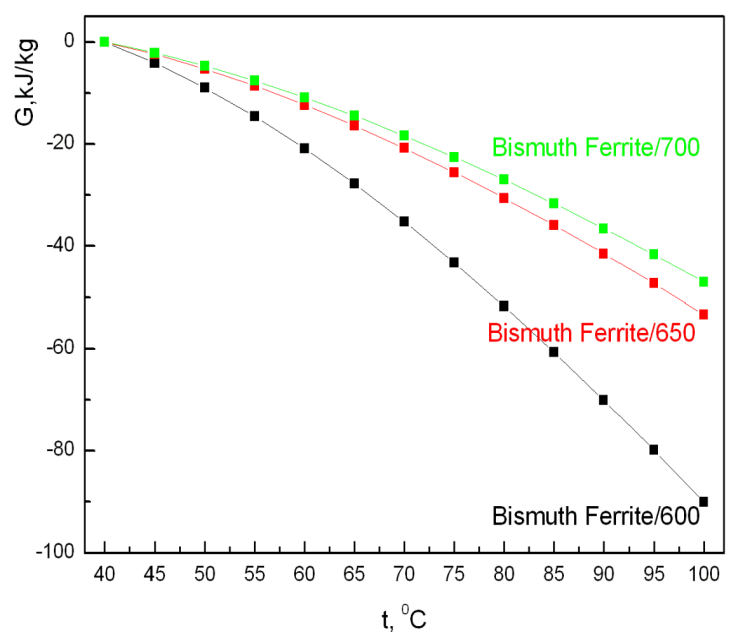

Fig. 9-Temperature dependences of the free energy (or Gibbs energy) of bismuth ferrites

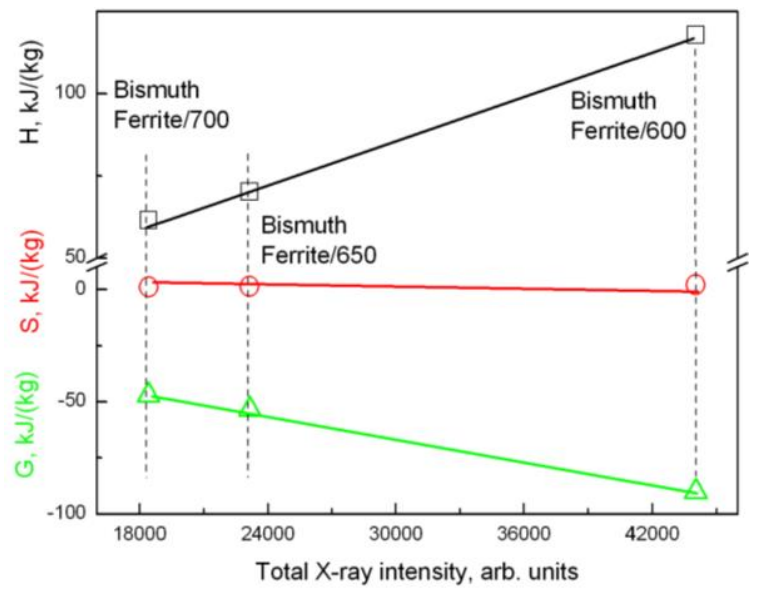

Fig. 10 - Correlation between the thermodynamic properties and the level of X-ray scattering on the studied samples

\section{REFERENCES}

1. Z. Alia, A. Atta, Y. Abbas, K. Sedeek, A. Adam, E. Abdeltwab, Thin Solid Films 577, 124 (2015).

2. A.A. Balandin, Nature Mater. 10, 569 (2011).

3. A. Bejan, Thermodynam. Today. Energy 160, 1208 (2018).

4. J.S. Blázquez, J.M. Borrego, C.F. Conde, A. Conde, S. LozanoPérez, J. Alloys Compd. 544, 73 (2012).

5. L. Boldon, F. Laliberte, L. Liu, Nano Rev. 6, 25661 (2015).

6. G. Catalan, J.F. Scott, Adv. Mater. 21, 2463 (2009).

7. X. Ding, Y. Liu, Pro Nat. Sci.: Mater. Int. 30 No 2, 153 (2020).

8. O. Fesenko, V. Korskanov, A. Yaremkevych, T. Tsebriinko, V. Dolgoshey, Appl. Nanosci. 10, 4609 (2020).

9. W. Greiner, L. Neise, H. Stocher, Thermodynamics and statistical mechanics (Springer-Verlag: 1995).

10. S.A. Khakhomov, V.E. Gaishun, D.L. Kovalenko, A.N. Pyatlitski, V.A. Solodukha, D.V. Karpinsky, INTERACADEMIA 2018: Recent Adv. Technol. Res. Ed. 43 (2019).

11. V.V. Korskanov, E.G. Privalko, V.P. Privalko, R. Walter, K. Friedrich, B. Calleja, F. José, Composite Polymer Mater. 25 No 2, 122 (2003)

12. V.V. Korskanov, I.L. Karpova, M.V. Ruhaylo, S.I. Lobok, Ceramics: Science and Life 32, No 3, 5 (2016) (in Russia).

13. Sh. Kossar, R. Amiruddin, A. Rasool, N.V. Giridharan, D. Dhayanithi, M.C. Santhosh Kumar, Superlattices Microstr. 148, 106726 (2020).

14. O. Kratky, I. Pilz, P.J. Schmitz, J. Colloid Interface Sci. 21
Therefore, based on independent investigation, it was established that the thermodynamic properties of the studied bismuth ferrites are determined by the scattering of thermal phonons by density fluctuations. On the other hand, the structural characteristics are determined by X-ray scattering by electron density fluctuations. This led to the presence of a direct correlation between the thermodynamic properties and the level of $\mathrm{X}$-ray scattering on the studied samples (Fig. 10).

\section{CONCLUSIONS}

A sol-gel method for the synthesis of bismuth ferrite is presented.

It was found that samples annealed at different temperatures have a granular microstructure with granule sizes from 20 to $100 \mathrm{~nm}$. On a scale above $200 \mathrm{~nm}$, all samples are morphologically the same.

X-ray diffraction studies discovered the crystallinity of bismuth ferrite at a scale level of less than one nanometer. Both sizes of bismuth ferrite nanocrystallites and overall structural heterogeneity decrease with increasing annealing temperature.

The thermodynamic analysis found a significant decrease in heat capacity, enthalpy, entropy and modulus of the Gibbs energy of the samples under study with an increase in the annealing temperature, indicating an improvement in the structure due to a decrease in heat loss on structural defects. The structure of the samples is formed according to the mechanism of joint crystallization of the components during cooling from the annealing temperature to room temperature. The samples obtained after annealing at the maximum temperature are characterized by the least defectiveness

It was found a direct correlation between the level of X-ray scattering on the studied samples and the thermodynamic properties of bismuth ferrites. There is reason to believe that by choosing an appropriate annealing temperature, it is possible to control the nanocrystallinity and thus other physical properties of bismuth ferrite.

No 1, 24 (1966).

15. Y.C. Liang, Phys. Procedia 32, 3149 (2012).

16. A. Manzoor, A.M. Afzal, M. Umair, A. Ali, M. Rizwan, M.Z. Yaqoob, J. Magn. Magn. Mater. 393, 269 (2015).

17. D.L. Nika, A.A. Balandin, Rep. Prog. Phys. 80, 036502 (2017).

18. Y. Rao, An Introduction to Thermodynamics (Sangam Books Ltd: 2004).

19. S. Panyata, S. Eitssayeam, G. Rujijanagul, T. Tunkasiri, K. Pengpat, Ceramics Int. 43, 407 (2017).

20. V.P. Privalko, R.V. Dinzhos, E.G. Privalko, Thermochimica Acta 432, 76 (2005).

21. V.P. Privalko, R.V. Dinzhos, E.G. Privalko, Thermochimica Acta 428 No 1-2, 31 (2005).

22. M. Sakar, S. Balakumar, P. Saravanan, S.N. Jaisankar, Mater. Res. Bull. 48 No 8, 2878 (2013).

23. A.Z. Simões, C.S. Riccardi, M.L. Dos Santos, G. Garcia, E. Longo, J.A. Varela, Mater. Res. Bull. 44 No 8, 1747 (2009).

24. H. Yokota, T. Kawakatsu, Polymer, 121975 (2020).

25. R. Verma, A. Chauhan, Neha, K.M. Batoo, R. Kumara, M.Hadhi, E.H. Raslan, Ceramics Int. 47 No 3, 3680 (2021).

26. S.E. Shirsath, R.H. Kadam, M.L. Mane, A. Ghasemi, Y. Yasukawa, X. Liu, A. Morisako, J. Alloys Compd. 575, 145 (2013).

27. S.J. Brinker, G.C. Frye, K.J. Ward, C.S. Ashley, J. NonCryst. Solids 121 No 1-3, 294 (1990). 


\section{Вплив температури відпалу на структуру та властивості феритів вісмута}

Валерій Корсканов ${ }^{1}$, Олена Фесенко ${ }^{1}$, Тамара Цебріенко ${ }^{1}$, Андрій Яремкевич ${ }^{1}$, Наталія Давиденко ${ }^{1}$, Володимир Долгошей ${ }^{2}$, Аліна Семченко ${ }^{3}$, Віталій Шидський ${ }^{3}$

${ }^{1}$ Інститут фбізики НАН України, відділ міжнародної науково-технічної діяльності, трансфберу технологій та захисту інтелектуальної власності, проспект Науки, 46, озоз9 Київ, Україна

${ }^{2}$ Національний технічний університет Украйни "Київський політехнічний інститут ім. Ігоря Сікорського», проспект Перемоги, 37, 03056 Київ, Україна

${ }^{3}$ Гомельський державний університет ім. Франииска Скорини, вул. Радянська, 104, 246019 Гомель, Білорусь

В статті представлені зразки фериту вісмуту, отримані авторами за допомогою золь-гель технології. Для встановлення морфології отриманих зразків застосовувалися методи скануючої електронної мікроскопії та енергодисперсійної спектроскопії. В роботі вивчалися дані з рентгеноструктурного аналізу та термодинамічні властивості зразків фериту вісмуту. Було показано, що зразки, відпалені при різних температурах, мають зернисту структуру з розмірами гранул від 20 до 100 нм. Однак у масштабі понад 200 нм усі зразки морфологічно не відрізняються. Дослідження дифракції рентгенівських променів виявило кристалічність фериту вісмуту на рівні масштабу менше одного нанометра. Розміри нанокристаліків фериту вісмуту та загальна структурна неоднорідність зменшуються із збільшенням температури відпалу. Термодинамічний аналіз виявив значне зменшення теплоемності, ентальпії, ентропії та модуля енергії Гіббса досліджуваних зразків із підвищенням температури відпалу. Це свідчить про поліпшення структури за рахунок зменшення тепловтрат на структурні дефекти. Встановлено пряму кореляцію між рівнем розсіювання рентгенівських променів на досліджуваних зразках та термодинамічними властивостями феритів вісмуту. $Є$ підстави вважати, що, вибравши відповідну температуру відпалу, можна регулювати нанокристалічність i, отже, інші фізичні властивості фериту вісмуту.

Ключові слова: Ферити вісмуту, Морфологія, Рентгенівське дослідження, Термодинамічні властивості, Нанокристалічність. 